\title{
Estudio de la alterabilidad y efecto de tratamientos de conservación para los ladrillos de la portada de la iglesia de Santa María de Jesús (Sevilla)
}

\author{
Brick durability and conservation treatment \\ (Santa María de Jesús chapel portal, Seville, Spain)
}

\author{
F. J. Alejandre(*), R. Villegas ${ }^{(*)}$
}

Recepción/Received: 13-II-07

Aceptación/Accepted: $31-\mathrm{X}-07$

Publicado online/Online publishing: 23-II-09

\section{RESUMEN}

Se ha estudiado la alteración diferencial de los 2 tipos de ladrillo de la iglesia de Santa María de Jesús (Sevilla) y 2 tratamientos para su restauración. Se han caracterizado por DRX y SEM, así como sus propiedades físicas, hídricas y mecánicas. Probetas preparadas de ladrillos de la iglesia se han sometido a ensayo de cristalización de sales para determinar las causas y los mecanismos de alteración.

El ladrillo rojo es el que presenta menor temperatura de cocción, menor porosidad y mayor proporción de microporos. Las propiedades físicas y mecánicas de ambos ladrillos no varían significativamente con los tratamientos, sólo las propiedades hídricas cambian con el hidrófugo. En el ensayo de alteración mejora mucho el comportamiento del ladrillo amarillo, mientras que en el rojo no varía la morfología de alteración (características de materiales con microporos) ni la durabilidad.

Palabras clave: ladrillo, tratamiento, alterabilidad, porosimetría, cristalización de sales.
SUMMARY

Durability differences of 2 types of brick from Santa María de Jesús Chapel (Sevilla) and 2 treatments for its restoration have been studied. They have been characterizad using XRD and SEM, as well as their physical, hydric and mechanical properties. Samples prepared with bricks from the chapel have been submitted to salt crystallization test, to identify decay causes and mechanisms.

The red brick present the lowest firing temperature, lower porosity and a great proportion of micropores. Physical and mechanical properties don't change significantly with the treatments, only hygric properties vary with the water repellent. The accelerated aging test revealed significant improvement in the behaviour of yellow brick, but no change in the decay mechanism of red brick (Typical of microporous materials) or its durability is observed.

Keywords: brick, treatment, decay, porosimetry, salt crystallization.
(*) Universidad de Sevilla.

Persona de contacto/Corresponding author: falejan@us.es 


\section{INTRODUCCIÓN}

El colegio de Santa María de Jesús fue uno de los centros más importantes de los estudios universitarios en la ciudad de Sevilla, el más antiguo, y finalmente el origen de la universidad sevillana. Fue fundado en 1506 por Rodrigo Fernández de Santaella. La utilización del edificio fue cambiando según las necesidades, pasando a posesión del Cabildo Catedralicio, que lo dedicó a Seminario Eclesiástico, después de perder su función universitaria.

El edificio del Colegio fue derruido a comienzos del siglo XX, coincidiendo con el ensanche de la Avenida de la Constitución y con la ampliación del espacio de la Puerta de Jerez, pero afortunadamente se conservó la capilla, arquitectónicamente intacta, salvo la solería que se sustituyó o tapó en 1963. La Capilla, junto con el nuevo edificio adyacente, está dedicada en la actualidad a alojar al Consejo General de Cofradías.

Por sus características formales y periodo de construcción, la capilla de Santa María de Jesús se cataloga dentro del estilo gótico-mudéjar. El edificio presenta tres fachadas: la principal, en Avenida de la Constitución, es un muro pantalla liso y pintado de blanco donde destaca su bella portada, mezcla curiosa de gótico isabelino y labor mudéjar, construida por Martín Sánchez en 1514 (Figura 1). Es una portada de ladrillo agramilado, es decir, tallado, y que alterna en su construcción dos tonos del ladrillo (amarillo y rojo), siendo el estado de conservación de ambos muy diferente (Figura 2). Se compone este vano de un arco conopial, flanqueado por baquetones y enmarcado por un alfiz gótico. Coronando la composición, se aprecia un rosetón, obra moderna que debe su origen a las reformas de la iglesia entre 1915 y $1920(1,2)$.

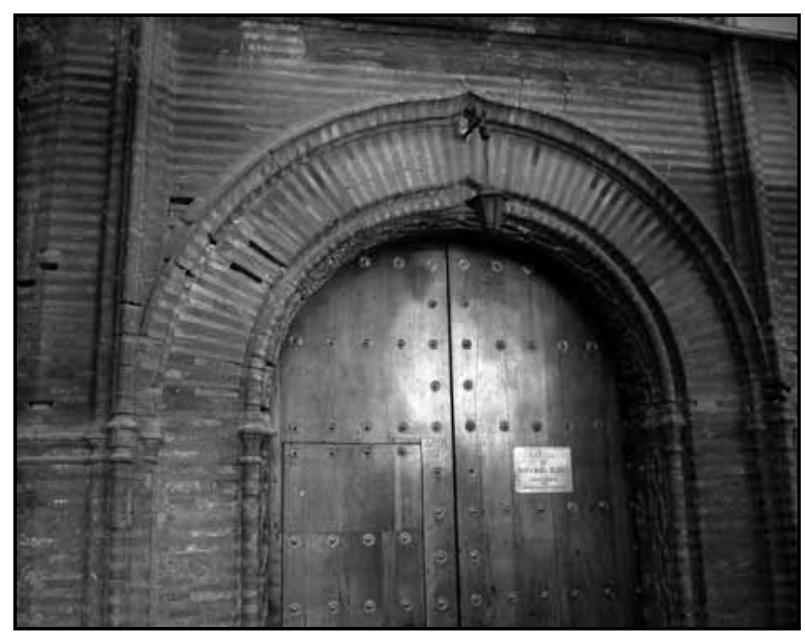

Figura 1. Portada de la iglesia de Sta. María de Jesús. Figure 1. Santa María de Jesús Chapel. Portal.

\section{INTRODUCTION}

Historically one of the Seville's main institutions for higher studies, Santa María de Jesús College, the kernel of its present university, was founded in 1506 by Rodrigo Fernández de Santaella. Over the years, building use has been adapted as needed. When acquired by the Cathedral Chapter, it was converted to a seminary.

The college building was demolished in the early twentieth century to widen Constitution Avenue and Jerez Gate. Fortunately, the chapel was left intact with the exception of the flooring, which was either replaced or covered over in 1963. The chapel and adjacent new building today house the headquarters of the General Council of Confraternities.

For its architecture and period of construction, Santa María de Jesús Chapel is regarded to be a MudejarGothic building. While the building has three facades, its main entrance faces Constitution Avenue. This plain whitewashed wall is embellished in the centre with a handsome portal, a peculiar blend of Isabelline Gothic and Mudejar styles, built by Martín Sánchez in 1514 (Figure 1). The state of conservation of the two alternating types (yellow and red) of carved brick used on the portal varies considerably (Figure 2). The portal constitutes an ogee arch with rounded moulding inside a Gothic "alfiz " or rectangular frame. The wall above contains a rose window, a modern element added to the facade during the $1915-1920$ renovation $(1,2)$.

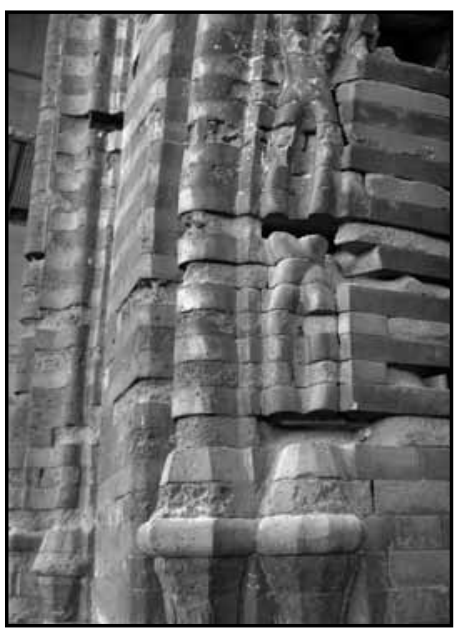

Figura 2. Detalle de la portada. Figure 2. Portal detail. 
En 2005 se acometió la restauración de la capilla y, como parte previa, se realizó la caracterización de los dos tipos de ladrillo empleados, de su estado de deterioro y causas de la alteración, de especial interés teniendo en cuenta el comportamiento tan diferente de ambos materiales.

Por otra parte, ante la poca información existente sobre el comportamiento de ladrillos tratados con consolidantes y/o hidrófugos, se consideró necesario estudiar previamente el efecto de estos tratamientos en probetas tomadas de la portada por medio de ensayos en laboratorio, antes de acometer su aplicación durante la restauración. En estas probetas se han medido diversas características, para determinar el resultado de los tratamientos, y se han sometido a un ensayo de alteración acelerada para estudiar la resistencia al principal agente de alteración que actúa en la portada, la cristalización de sales.

\section{MATERIALES Y METODOLOGÍA}

\subsection{Materiales: ladrillos y productos de tratamiento}

Para la realización de los distintos ensayos y determinaciones se tomaron dos ladrillos de la portada, uno de cada tipo, con los que se prepararon probetas cúbicas de $4 \mathrm{~cm}$ de arista. Después del corte y antes de la impregnación con los productos, las probetas se han limpiado y dejado secar al aire, para conseguir un contenido de humedad higroscópica en equilibrio con el ambiente. Las probetas se han tratado por inmersión completa durante veinte minutos. Los productos han sido seleccionados por el restaurador responsable de la intervención (Tabla 1 ), no pudiéndose incluir un mayor número por no disponer de cantidad suficiente de probetas. Se han aplicado tal y como se suministran por el fabricante, de la misma manera que se hace en la intervención real.
One of the first stages of the chapel restoration works undertaken in 2005 was to characterize the brick and determine its state of conservation and causes of decay. This was particularly important due to the visible differences in the condition of the two materials.

Moreover, in light of the scant information available on the behaviour of bricks treated with consolidants and/or water repellents, laboratory trials were required to study the effect of these treatments on portal specimens before application to the portal brick. A number of specimen characteristics were explored to determine the effect of the treatments. Accelerated ageing tests were also conducted on the samples to study their resistance to salt crystallization, the primary agent of decay.

\section{MATERIALS AND METHODS}

\subsection{Materials: bricks and treatment products}

One brick of each type was removed from the portal for trials and characterization. Four-cm cubic specimens were cut from the bricks. Prior to impregnation, the specimens were cleaned and air-dried to ambient humidity levels. The samples were immersed completely for twenty minutes in the treatments chosen by the head restorer (Table 1). The number of treatments was limited by the small amount of material available for testing. The products were used to manufacturer instructions for the trials, just as they would be for the actual intervention.

Tabla 1 / Table 1

Características de los tratamientos.

Treatment characteristics.

\begin{tabular}{|c|c|c|}
\hline Producto / Treatment & Fabricante / Manufacturer & Composición / Composition \\
\hline $\begin{array}{c}\text { Estel } 1000 \\
\text { Consolidante / Consolidant }\end{array}$ & CTS España & $\begin{array}{c}\text { Ésteres etílicos del ácido silícico (75\% tetra-etil-orto-silicato) / } \\
\text { Silicic acid ethyl esters (75\% tetra-ethyl-ortho-silicate) }\end{array}$ \\
\hline $\begin{array}{c}\text { FTB hydro es } \\
\text { Hidrofugante / Water repellent }\end{array}$ & FTB & $\begin{array}{c}\text { Oligosiloxano modificado (6\% de materia activa) / } \\
\text { Modified oligosiloxane (6\% active compound) }\end{array}$ \\
\hline
\end{tabular}

De cada tipo de ladrillo se han tratado 3 probetas con el consolidante Estel 1000 y otras 3 con el consolidante en primer lugar $y$, tras su secado, con el hidrófugo FTB hydro es. Tras la impregnación se ha controlado el peso
Three specimens of each type of brick were treated with Estel 1000, a consolidant, and a further three first with the consolidant and, once dry, with a water repellent, FTB hydro es. After impregnation, sample weight was 
de las probetas hasta un valor constante. De esta forma se ha determinado el tiempo de secado, el incremento de peso, y, posteriormente, se ha medido la variación de porosidad.

\subsection{Técnicas de caracterización de los ladrillos}

La composición mineralógica de los dos ladrillos se ha determinado mediante DRX utilizando un difractómetro Bruker-AXS D8 Advance equipado con un filamento de cobre, CuK $\alpha$, condiciones del tubo de $40 \mathrm{kV}$ y $30 \mathrm{~mA}$, rendija fija y detector de centelleo. Los difractogramas se obtuvieron mediante la técnica de polvo, en un rango $2 \theta$ de $3^{\circ}$ a $70^{\circ}$ aplicando un paso de $0,03^{\circ}$ y tiempo de paso de $1 \mathrm{~s}$.

La textura superficial fue examinada por medio de un microscopio electrónico de barrido, obteniéndose además su análisis químico elemental. El equipo utilizado fue un Jeol JSM 6460-LV, equipado con una microsonda de energía dispersiva de RX (EDX), una ventana de berilio ATW2 y un software especifico (Oxford INCA) para análisis químico semicuantitativo. Las imágenes de fragmentos de ladrillos metalizados con oro fueron adquiridas en el modo de electrones secundarios (SE).

La determinación de la resistencia a compresión se ha realizado sobre tres probetas de cada ladrillo. La metodología de ensayo seguida ha sido la indicada en la norma UNE-EN 772-1 (3), adaptándola a las probetas disponibles de $4 \times 4 \times 4 \mathrm{~cm}$. Dado que no se disponía de gran cantidad de muestras, al ser un ensayo destructivo, la resistencia a compresión sólo se ha medido en las probetas sin tratar.

\subsection{Evaluación de tratamientos}

Para estudiar el comportamiento de los tratamientos y determinar su idoneidad se ha seguido la metodología puesta a punto en el I.A.P.H. $(4,5,6)$ consistente en estudiar tres aspectos:

- Compatibilidad del tratamiento con el material.

- Eficacia del tratamiento.

- Resistencia del material tratado a la alteración.

\subsubsection{Compatibilidad del tratamiento con el material}

Para determinar si un tratamiento es aceptable, es fundamental conocer cómo modifica algunas características del material. En este aspecto se podrían englobar tanto la aparición de reacciones secundarias con el substrato (como sucede cuando se utilizan tratamientos a base de ácidos en materiales calizos), la permanencia de residuos del tipo de compuestos solubles (como la aparición de monitored until a constant value was reached. Drying time, weight gain and the variation in porosity were measured.

\subsection{Brick characterization}

The mineralogical composition of the two bricks was determined by X-ray diffraction (XRD) using a BrukerAXS D8 Advance powder diffractometer with CuK $\alpha$ radiation, operating at $40 \mathrm{kV}$ and $30 \mathrm{~mA}$ with a fixed slit and a scintillation counter. The diffractograms were obtained with a $2 \theta$ scanning range of $3^{\circ}$ to $70^{\circ}$, and scan step and time of $0.03^{\circ}$ and 1 , respectively.

Scanning electron microscope analyses were conducted to view the surface texture and determine the elemental composition of the samples, using a Jeol JSM 6460$L V$ device coupled to an EDX microprobe and fitted with an ATW2 beryllium window. Semi-quantitative analysis was performed with Oxford INCA software. Brick fragments were gold sputtered for secondary electron (SE) imaging.

Compressive strength was determined on three samples of each brick as specified in Spanish and European standard UNE-EN 772-1 (3), adapted to the $4 \times 4 \times 4-\mathrm{cm}$ specimen size. Given specimen scarcity and since the test is destructive, compressive strength was measured in the untreated samples only.

\subsection{Treatment evaluation}

Three aspects of the treatments were studied (following the methodology proposed by I.A.P.H. $(4,5,6)$ :

- Treatment-material compatibility.

- Treatment effectiveness.

- Resistance of treated material to decay.

\subsubsection{Treatment-material compatibility}

An understanding of how a treatment modifies certain characteristics of the material to which it is applied is requisite to determining its suitability. The aspects to be studied in this regard include the appearance of secondary reactions with the substrate (such as when acid-based products are used on limestone), the existence of residues from soluble compounds (such as 
sales alcalinas cuando se aplican silicatos solubles) o la modificación de algunas características del material que son fundamentales en su alterabilidad.

Aquí se pueden considerar aquellas propiedades que están relacionadas con la capacidad de transferencia de humedad del material. Normalmente, al aplicar un tratamiento como los estudiados aquí, esta capacidad se ve modificada en sentido negativo, de forma que, cuando el agua (que puede penetrar en el material por vías muy diversas) intenta salir hacia la superficie exterior, podrían producirse acumulaciones en la interfase entre la zona tratada externa y el interior sin tratar. Esto conlleva riesgos de hidratación o disolución de sales en esa zona o congelación, todo lo cual podría producir el desprendimiento de la capa tratada. Este aspecto puede cuantificarse midiendo aquellas propiedades relacionadas con el sistema poroso, como la porosidad total y la distribución del tamaño de poros.

La determinación de la porosidad abierta se ha realizado por el método de absorción de agua a vacío según norma EN-1936 (7) sobre todas las probetas rojas y amarillas antes del tratamiento y sobre las probetas tratadas después de la impregnación.

La distribución de tamaños de poros se ha determinado en un porosímetro Carlo Erba modelo P-2000.

\subsubsection{Eficacia del tratamiento}

El objetivo de la aplicación de un tratamiento es conseguir una mejora en determinadas características del material. En el caso de los productos hidrófugos se trata de disminuir la entrada de agua en el mismo y, en el caso de los consolidantes, aumentar la cohesión del material. Para poder cuantificar esta mejora se determina, en el primer caso, cómo se modifica la absorción de agua y, en el segundo, se miden las propiedades mecánicas.

La determinación de la absorción de agua por capilaridad se ha realizado siguiendo la metodología propuesta por la comisión RILEM 25-PEM (8). Las medidas se han realizado sobre las probetas tratadas y sin tratar de ambos tipos de ladrillo.

Para determinar el efecto de mejora en la cohesión del material se determinan las propiedades mecánicas, ya sea globales -resistencia a la compresión o flexión, fundamentalmente- o superficiales. La resistencia superficial puede ser un valor más representativo del efecto de los tratamientos, que normalmente se manifiesta en una capa superficial. Además, presenta la ventaja de ser un ensayo no destructivo.

La medida de la dureza superficial que se ha realizado se basa en la resistencia que opone un material a ser alkaline salts when soluble silicates are used), and the modification of characteristics essential to material durability.

Properties relating to moisture transferability of the brick were likewise studied. Normally, treatments reduce moisture flow in the substrate. As a result, when water inside the material (which it may penetrate in a variety of ways) seeks an outlet, moisture may accumulate at the interface between the outer (treated) and the inner (untreated) zones. This raises the risk of hydration, salt dissolution or even freezing in this area, any of which may ultimately cause the coating to peel away. Moistureflow capacity can be quantified by measuring properties related to the pore system, such as total porosity and pore size distribution.

Vacuum water absorption (European standard EN-1936 (7)) was used to determine open porosity in all the treated and untreated red and yellow bricks.

The pore-size distribution was found with a Carlo Erba P2000 porosimeter.

\subsubsection{Treatment effectiveness}

Treatments are applied to improve certain characteristics of the treated material. With water repellents, the aim is to reduce water absorption, and with consolidants, to increase material cohesion. Water repellent-induced improvements are quantified by measuring changes in water absorption, while the improvements mediated by consolidants are measured in terms of mechanical properties.

Capillary uptake was found as proposed by RILEM Commission 25-PEM (8). Measurements were taken on treated and untreated samples of both types of brick.

Improvements in material cohesion are determined on the grounds of both mechanical (primarily compressive strength) and surface properties. Surface strength may be more representative of treatment effectiveness, for it can normally be detected on the outermost layer. Moreover, the respective test is nondestructive.

A material's surface strength is measured as its resistance to impact by a harder body. Both the treated 
penetrado por un cuerpo más duro. La dureza de las probetas tratadas y sin tratar se ha medido con un durómetro tipo Brinell, empleando una bola de $5 \mathrm{~mm}$, aplicando una precarga de $10 \mathrm{~kg}$ y una carga total de $30 \mathrm{~kg}$. El valor de la dureza se determina como función inversa de la diferencia entre la penetración de la bola con la carga de $30 \mathrm{~kg}$ y con la carga de $10 \mathrm{~kg}$. El intervalo de medida oscila entre 0-130 unidades de dureza Brinell. En cada probeta se han realizado 4 medidas en cada una de las tres caras perpendiculares que confluyen en un vértice, en total 12 medidas, calculando los valores medios por probeta y por tratamiento. Se ha medido sobre todas las probetas rojas y amarillas antes del tratamiento y, posteriormente, sobre las mismas probetas después de aplicar los tratamientos.

\subsubsection{Resistencia a la alteración. Ensayos de alteración acelerada}

El último paso en la evaluación de un tratamiento consiste en someter las probetas a condiciones que simulen los mecanismos de alteración observados en el edificio, pero de forma concentrada en el tiempo, para obtener resultados en plazos más breves. En este caso el mecanismo más determinante del estado de los materiales es la cristalización de las sales presentes en los ladrillos, por lo que se ha llevado a cabo el ensayo de alteración de cristalización de sales.

Este ensayo consiste en someter a las probetas a cristalizaciones y solubilizaciones sucesivas de una sal soluble. Se ha realizado siguiendo el ensayo propuesto dentro del Programa de Normalización de Estudios previos del IAPH (9), utilizando una solución de sulfato sódico al $10 \%$ ( $p / v)$ con ciclos formados por las siguientes fases: a) inmersión, de 24 horas, y b) secado, de 22 horas a $65^{\circ} \mathrm{C}$ en estufa con 2 horas de enfriamiento previas a la pesada. Una variante del ensayo clásico la lleva a cabo van Hees (10), estudiando el deterioro de las probetas preparadas con ladrillos y mortero, durante un largo periodo de tiempo (hasta dos años) después de haberlas impregnado con la sal.

Cuando las probetas, tras el secado, impregnadas de tenardita (sulfato sódico anhidro) se introducen nuevamente en la disolución, se produce la solubilización de la tenardita a temperatura ambiente, lo cual origina una disolución muy sobresaturada en mirabilita $\left(\mathrm{Na}_{2} \mathrm{SO}_{4} \cdot 10 \mathrm{H}_{2} \mathrm{O}\right)$. Al precipitar la mirabilita se generan enormes tensiones de cristalización $(11,12)$. En el caso de materiales con poros con radio de entrada inferior a 0,01 $\mu \mathrm{m}$ (microporos) la sobresaturación puede alcanzar valores aún mayores $(13,14,15)$ y las tensiones de cristalización pueden superar fácilmente los valores habituales de resistencia de los materiales de construcción. and untreated samples were tested for hardness with the Brinell method, using a 5-mm $\varnothing$ ball, initially with a force of ten and subsequently with a force of $30 \mathrm{~kg}$. Hardness is defined to be the inverse function of the difference between the $30-\mathrm{kg}$ and $10-\mathrm{kg}$ indentation. The Brinell scale ranges from 0 to 130 hardness numbers $(H B)$. Four measurements were made on each of the three perpendicular sides of a specimen converging on one of the corners, for a total of 12 measurements. The average values per sample and per treatment were calculated. All the red and yellow brick samples were measured both before and after treatment.

\subsubsection{Durability. Accelerated weathering tests}

The final step in treatment evaluation consisted in subjecting the samples to conditions that simulated the weathering agents acting on the building, condensed into a short period of time. Since in this case salt crystallization was the mechanism to which the bricks were primarily exposed, salty crystallization ageing tests were conducted.

This test consists in subjecting samples to successive salt crystallization and dissolution. It was conducted as stipulated in the IAPH Programme of Standards of Initial Studies prior to intervention (9): i.e., soaking the specimens in a $10 \%$ solution of sodium sulphate $(w / v)$ for 24 hours, followed by oven drying for 22 hours at $65^{\circ} \mathrm{C}$ and two hours of cooling time before weighing. Van Hees (10) proposed a variation on this classic procedure, studying decay in salt-soaked brick and mortar samples over very long periods (up to two years).

After drying, when the samples impregnated with thenardite (anhydrous sodium sulphate), which is soluble at ambient temperature, are re-soaked, the result is a supersaturated mirabilite $\left(\mathrm{Na}_{2} \mathrm{SO}_{4} \cdot 10 \mathrm{H}_{2} \mathrm{O}\right)$ solution. As the mirabilite precipitates, enormous crystallization pressure is generated $(11,12)$. In materials with a pore radius of under $0.01 \mu \mathrm{m}$ (micropores), supersaturation may become even more intense (12, 14, 15), with crystallization pressures substantially higher than can normally be resisted by construction materials. 
Esta prueba se ha llevado a cabo con tres probetas sin tratar y tres tratadas con cada producto, para cada ladriIlo. A lo largo del ensayo se efectúa el control del peso de las probetas en cada ciclo y de las alteraciones macroscópicas que van apareciendo. Cuando el grado de deterioro alcanzado por una probeta es grande se elimina del ensayo.

\section{RESULTADOS}

\subsection{Ladrillos}

\subsubsection{Composición mineralógica}

En la Figura 3 se recogen los difractogramas de las dos muestras con las distintas fases identificadas.
The test was conducted with each product on three treated and three untreated samples of each brick type. Sample weight was monitored in all cycles throughout the trial and note was taken of any macroscopic changes. Intensely decayed samples were eliminated from the test.

\section{RESULTS}

\subsection{Bricks}

\subsubsection{Mineralogy}

The diffractograms for the two specimens, on which the various phases are identified, are shown in Figure 3.

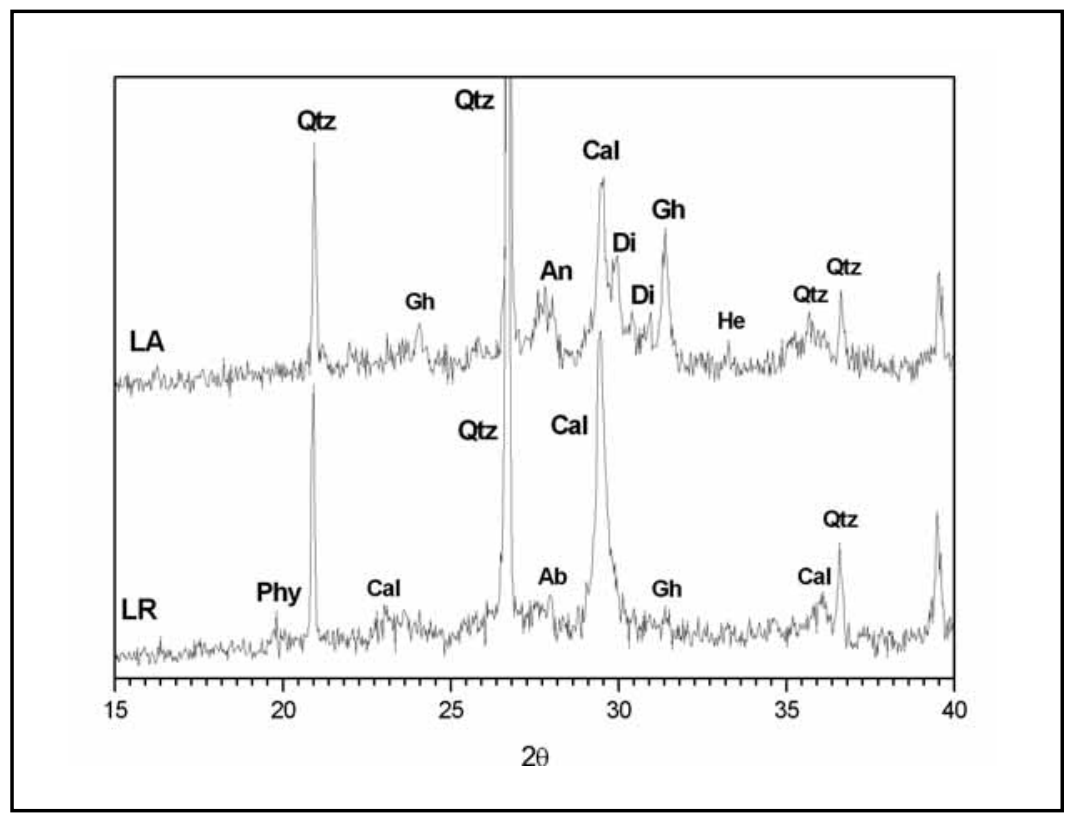

Figura 3. Difractogramas del ladrillo rojo (LR) y amarillo (LA) en el rango significativo de $15^{\circ}-40^{\circ}$. Abreviaturas: Phy=filosilicatos, $Q t z=c u a r z o, C a l=c a l c i t a, G h=$ gehlenita, $\mathrm{Di}=$ diópsido, $A n=$ anortita, $A b=a l b i t a$ y $\mathrm{He}=$ hematites.

Figure 3. Diffraction patterns of red (LR) and yellow (LA) bricks in the range $15^{\circ}-40^{\circ}$. Abbreviations: Phy=phyllosilicates, $Q t z=q u a r z t, C a l=c a l c i t e, G h=$ gehlenite, $D i=d i o p s i d e, A n=a n o r t h i t e, A b=a l b i t e$, and $\mathrm{He}=$ haematites.

La mineralogía presente en los dos ladrillos hace pensar que la temperatura de cocción no llegó a alcanzar en ningún caso los $900{ }^{\circ} \mathrm{C}$, dado que existe calcita que es una fase que desaparece a $\mathrm{T} \geq 870{ }^{\circ} \mathrm{C}(16)$. Esta calcita puede proceder tanto de la materia prima original (primaria), que no se ha descarbonatado completamente, como de $\mathrm{CaO}$ producido durante la cocción, fase que posteriormente se hidrata al estar expuesta a la humedad, y da lugar a la
The presence of calcite in both bricks is strong evidence that the firing temperature never exceeded $900{ }^{\circ} \mathrm{C}$, since this phase disappears at temperatures of $\geq 870^{\circ} \mathrm{C}$ or over (16). The calcite may have been either primary, i.e., present in the original raw material (in which case it was not fully decarbonated), or secondary, a result of the hydration of the $\mathrm{CaO}$ generated during firing. The portlandite 
portlandita $\mathrm{Ca}(\mathrm{OH})_{2}$, que a continuación se recarbonata produciendo nuevamente calcita (secundaria).

En el caso del ladrillo rojo además se puede apreciar cómo existe mayor cantidad de calcita que en el amariIlo, la presencia de reflexiones correspondientes a filosilicatos (a $700{ }^{\circ} \mathrm{C}$ sólo illita/moscovita deshidratadas permanecen), y la existencia de trazas de silicatos de alta temperatura, en concreto gehlenita. Esta fase es un silicato alumino-cálcico que procede de la reacción entre minerales presentes en las arcillas (illita y esmectitas) con la calcita (16) apareciendo a $800^{\circ} \mathrm{C}$ e incrementando su concentración hasta los $900^{\circ} \mathrm{C}$. Todos estos datos permiten establecer que la temperatura de cocción de este ladrillo fue inferior a $800{ }^{\circ} \mathrm{C}$.

Para el ladrillo amarillo se puede observar que existe menor cantidad de calcita, mayor cantidad de gehlenita (fase que incrementa su concentración hasta los $900^{\circ} \mathrm{C}$ ) y se ha identificado la presencia de diópsido (silicato magnésico) que indica que en la materia prima había dolomita u otro mineral conteniendo magnesio; esta fase se origina a partir de los $850{ }^{\circ} \mathrm{C}$. Finalmente existen trazas de hematites, fase que se origina por la transformación de otros óxidos de hierro a temperaturas superiores a los $850^{\circ} \mathrm{C}$. Con esta información se puede afirmar que la temperatura de cocción de este ladrillo fue de unos $850^{\circ} \mathrm{C}$ y que está fabricado con una materia prima diferente al ladrillo rojo.

\subsubsection{Resistencia a compresión}

Los resultados obtenidos para cada probeta se recogen en la Tabla 2.
$\left(\mathrm{Ca}(\mathrm{OH})_{2}\right)$ thus formed would be subsequently recarbonated to calcite.

The red brick was found to contain larger amounts of calcite, peaks corresponding to phyllosilicates (at $700{ }^{\circ} \mathrm{C}$ only dehydrated illite and muscovite remained), and traces of gehlenite, a high-temperature silicate. Gehlenite is an aluminium-calcium silicate, a product of the reaction between clay minerals (illite and smectite) and calcite (16), appearing at $800^{\circ} \mathrm{C}$ and increasing in concentration up to $900^{\circ} \mathrm{C}$. Based on the foregoing, the firing temperature of this brick was established to be under $800^{\circ} \mathrm{C}$

The yellow brick contained smaller amounts of calcite but more gehlenite. The presence of diopside (magnesium silicate), which appears at $850^{\circ} \mathrm{C}$, was an indication that the raw material contained dolomite or some other magnesium-bearing mineral. Finally, traces of hematite, the product of the transformation of other iron oxides at temperatures of over $850{ }^{\circ} \mathrm{C}$ were also observed. Further to these findings, the yellow brick was clearly fired at a temperature of around $850^{\circ} \mathrm{C}$ and made from a different raw material than the red brick.

\subsubsection{Compressive strength}

Table 2 gives the results for each sample.

Tabla 2 / Table 2

Resistencia a compresión. Compressive strength.

\begin{tabular}{|c|c|c|}
\hline & Ladrillo rojo / Red brick & Ladrillo amarillo / Yellow brick \\
\hline Probeta 7 / Specimen 7 & $267.6 \mathrm{Kp} / \mathrm{cm}^{2}$ & $139.7 \mathrm{Kp} / \mathrm{cm}^{2}$ (eliminado / not considered) \\
\hline Probeta 8 / Specimen 8 & $116.4 \mathrm{Kp} / \mathrm{cm}^{2}$ (eliminado / not considered) & $189.5 \mathrm{Kp} / \mathrm{cm}^{2}$ \\
\hline Probeta 9 / Specimen 9 & $231.6 \mathrm{Kp} / \mathrm{cm}^{2}$ & $186.7 \mathrm{Kp} / \mathrm{cm}^{2}$ \\
\hline Rc media / Average & $250 \mathrm{Kp} / \mathrm{cm}^{2}\left(25,0 \mathrm{~N} / \mathrm{mm}^{2}\right)$ & $188 \mathrm{Kp} / \mathrm{cm}^{2}\left(18,8 \mathrm{~N} / \mathrm{mm}^{2}\right)$ \\
\hline
\end{tabular}

Para calcular el valor medio se han eliminado los valores con dispersión de resultados mayor del $10 \%$. Se observa la mayor resistencia del ladrillo rojo, del orden de un $20 \%$ superior.

\subsection{Aplicación de los tratamientos}

El control de peso durante el secado evidencia que el consolidante tarda aproximadamente 15 días en secarse por completo, ya que este tipo de productos se aplica en forma de monómeros y deben polimerizar dentro de los poros de la cerámica para dar sílice coloidal. El hidrófugo
Results deviating by more than $10 \%$ were eliminated to calculate the mean. Note the greater resistance of the red brick samples (about 20\% higher).

\subsection{Application of treatments}

Weight monitoring during drying revealed that the consolidant took approximately 15 days to dry completely, because this type of product is applied as a monomer and must polymerize inside the brick pores to produce colloidal silica. The water repellent in turn, which is sold 
tarda menos de 15 días en completar el proceso, ya que es un producto que está parcialmente polimerizado. Las reacciones que experimentan este tipo de productos durante el proceso de curado se recogen en (17) y (18).

Los incrementos de peso experimentados por las probetas son proporcionales a los contenidos de materia activa de los tratamientos (Tablas 1 y 3). El incremento de peso final es muy semejante en ambos ladrillos, con un valor muy superior en el caso del consolidante, como corresponde a un mayor contenido de materia activa (Tabla 1). partially polymerized, took less than 15 days to dry. The curing reactions involved are given in (17) and (18).

The weight gains were proportional to the active compound content in the treatments (Tables 1 and 3). The final weight was very similar in the two types of brick, with much higher values for the consolidant due to the greater amounts of active compounds in its composition (Table 1).

Tabla 3 / Table 3

Incremento de peso (\%) de las probetas tras el secado de los tratamientos. Post-treatment weight increase (\%) of samples.

\begin{tabular}{|c|c|c|}
\hline Ladrillo / Brick & Estel 1000 & FTB hydro es \\
\hline Rojo / Red & 1.93 & 0.16 \\
\hline Amarillo / Yellow & 1.84 & 0.22 \\
\hline
\end{tabular}

El microscopio electrónico de barrido ha puesto de manifiesto la distribución de los tratamientos en la superficie de ambos ladrillos, como se aprecia en las Figuras 4 y 5.
Scanning electron microscopy revealed a fairly even distribution of the treatments on the brick surfaces (Figures 4 and 5), although the products were observed to
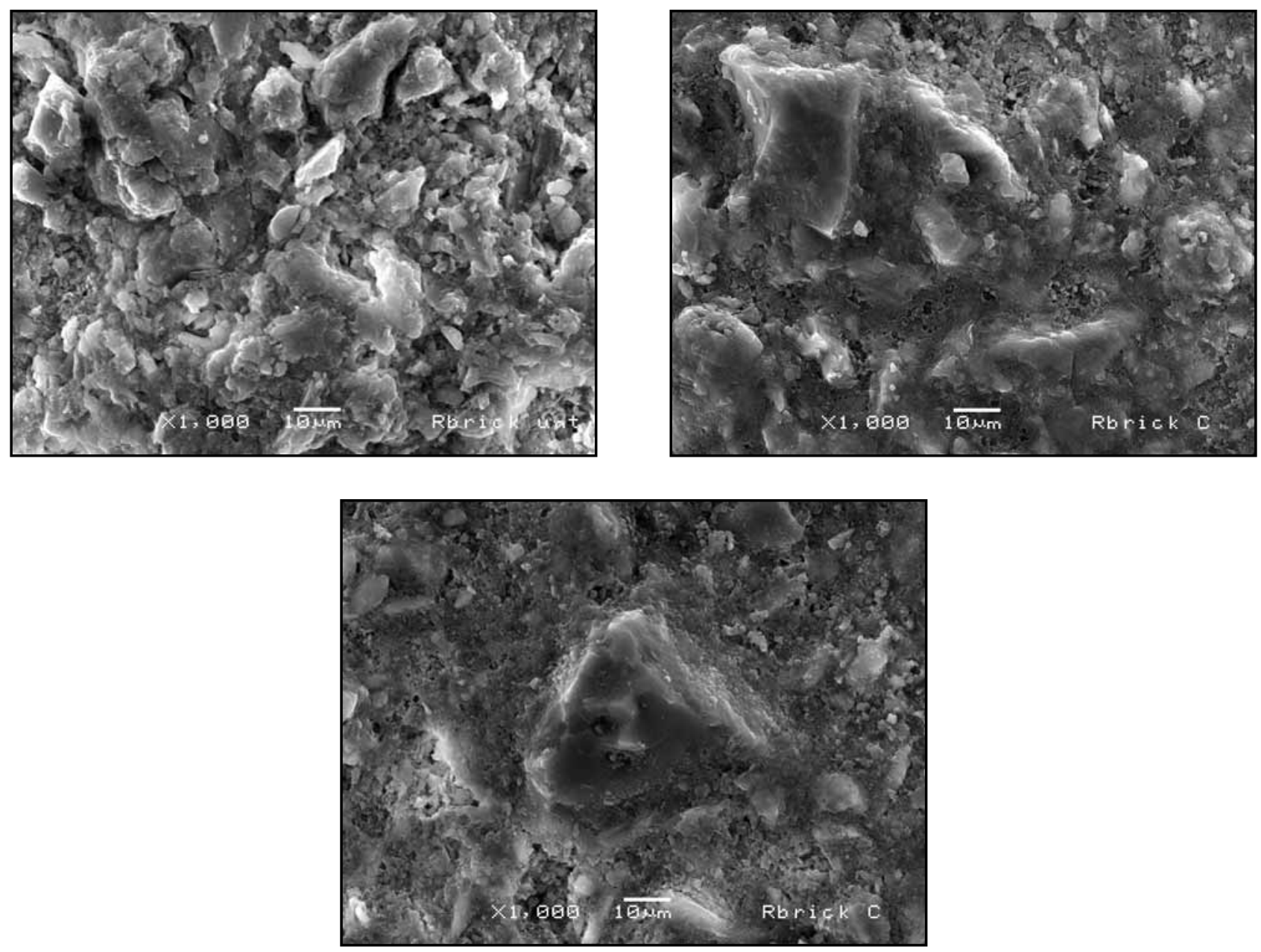

Figura 4. a) Superficie ladrillo rojo sin tratar; b) tratado con el consolidante; c) tratado con consolidante e hidrófugo. Figure 4. Red brick surface: a) untreated; b) treated with consolidant; c) treated with consolidant plus water repellent. 
El producto recubre de manera bastante uniforme la superficie, aunque en las zonas más profundas se producen acumulaciones, lo cual se ha confirmado por medio de microanálisis EDX, que identifica la presencia solamente de silicio y oxígeno en dichas zonas. No hay diferencias entre los dos tipos de ladrillo por lo que respecta a la película formada por los tratamientos.

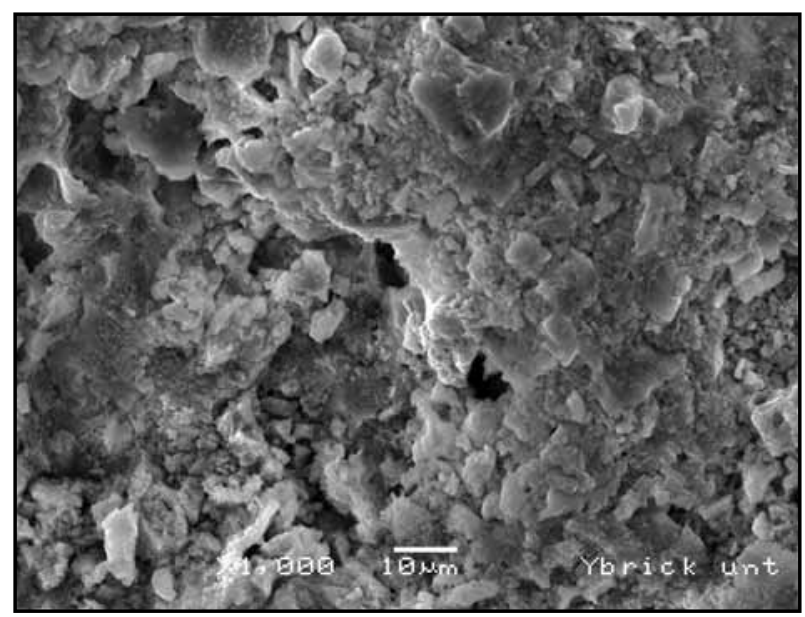

accumulate at greater depths, where EDX microanalysis confirmed the presence of silica and oxygen only. No differences were found between the two types of brick with respect to treatment coating.

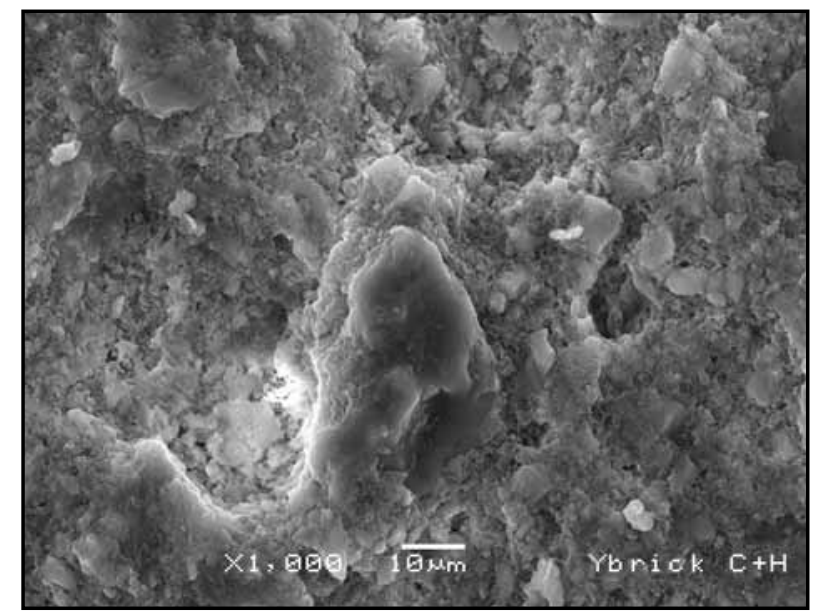

Figura 5. a) Superficie ladrillo amarillo sin tratar; b) tratado con el consolidante; c) tratado con consolidante e hidrófugo. Figure 5. Yellow-brick surface: a) untreated; b) treated with consolidant; and c) treated with consolidant and water repellent.

\subsection{Evaluación de tratamientos}

\subsubsection{Compatibilidad con el material}

La porosidad media de las tres probetas tratadas con cada producto se recoge en la Tabla 4.

El primer resultado que se debe comentar es la elevada diferencia de porosidad entre los ladrillos rojos y amarillos, casi un $5 \%$, y que tiene su origen tanto en la materia prima con la que se elaboraron como en las distintas temperaturas de cocción. La influencia de la temperatura de cocción en la porosidad de ladrillos procedentes de

\subsection{Treatment evaluation}

\subsubsection{Treatment-material compatibility}

The average porosity of the three samples treated with each product is given in Table 4.

The findings revealed a clear difference (nearly $5 \%$ ) in red and yellow brick porosity, as a result of the differences in raw materials and firing temperatures. The effect of firing temperature on the porosity of bricks made from calcareous and non-calcareous raw materials was the subject of a previous study (19). Those authors 
Tabla 4 / Table 4

Porosidad abierta media (\%).

Mean open porosity (\%).

\begin{tabular}{|c|c|c|c|}
\hline Ladrillo / Brick & Sin Tratamiento / Untreated & Estel 1000 & Estel 1000 + FTB Hydro es \\
\hline Rojo / Red & 37.1 & 32.5 & 30.6 \\
\hline Amarillo / Yellow & 43.0 & 38.7 & 35.4 \\
\hline
\end{tabular}

materias primas no calcáreas y calcáreas se ha estudiado (19), encontrándose para los calcáreos los siguientes valores, a $700{ }^{\circ} \mathrm{C}$ un $36,14 \%$, a $800{ }^{\circ} \mathrm{C}$ un $40,13 \%$ y a $900^{\circ} \mathrm{C}$ un $36,97 \%$, valores que guardan concordancia con los del ladrillo rojo ( $750^{\circ} \mathrm{C}$ aprox.) y el amarillo $\left(850^{\circ} \mathrm{C}\right)$. En general existen referencias que establecen la porosidad abierta de los ladrillos macizos en el intervalo que va del $35 \%$ al $37 \%$ (20) y, otros autores (21) amplían el intervalo de porosidad abierta del $35 \%$ al $42 \%$, pudiéndose considerar que el valor obtenido para la muestra del ladrillo rojo está dentro de los intervalos considerados normales, y en el caso del ladrillo amarillo ha sido más alta que el límite superior establecido como normal.

Con el empleo del consolidante se observa que la porosidad ha descendido sobre un $4 \%$ en ambas muestras, efecto que se debe a la precipitación de gel de sílice en el sistema poroso del ladrillo por la hidrólisis y polimerización del silicato de etilo.

En el caso del tratamiento consolidante + hidrofugante se produce nuevamente un descenso en la porosidad, sobre un $2 \%-3 \%$, que se debe a la presencia del hidrofugante en las paredes de los poros. En este caso la disminución es menor ya que este producto se deposita en menor cantidad al estar el principio activo en menor concentración.

Por lo que se refiere a la distribución de tamaños de poros, se aprecia que es muy diferente para ambos ladrillos (Figuras 6a y 7a): el ladrillo rojo tiene todos los poros de tamaño inferior a $1 \mu \mathrm{m}$ de radio, con un volumen considerable por debajo de $0,1 \mu \mathrm{m}$; por el contrario, el ladrillo amarillo presenta un gran volumen de poros entre 0,1 y $1 \mu \mathrm{m}$, muy poco volumen por debajo de $0,1 \mu \mathrm{m}$ y bastante volumen de poros que llegan a alcanzar los $4 \mu \mathrm{m}$ de radio.

Para los ladrillos calcáreos cocidos a temperaturas inferiores a $1.100{ }^{\circ} \mathrm{C}$ es normal que la mayor parte del volumen de poros esté dentro del intervalo de radios situado entre 0,01 y $1 \mu \mathrm{m}$ (19). Estudios de porometría por intrusión de mercurio y análisis digital de imagen (19) muestran cómo ladrillos calcáreos cocidos a $800{ }^{\circ} \mathrm{C}$ y sobre todo a $900{ }^{\circ} \mathrm{C}$ muestran un ligero aumento de los poros hacia radios $>1 \mu \mathrm{m}$.

Con los tratamientos cambia ligeramente la distribución de tamaños. En las muestras de ladrillo rojo (Figuras 6a, reported porosities of $36,14 \%, 40,13 \%$ and $36,97 \%$ for 700, 800 and $900{ }^{\circ} \mathrm{C}$, respectively, all of which concurred with the values found for the red (approx. $700^{\circ} \mathrm{C}$ ) and yellow $\left(850^{\circ} \mathrm{C}\right)$ bricks. A number of sources concur that in solid brick, open porosity ranges from 35$37 \%$ (20), although other authors extend the range to $35-42 \%$. In that context, while the value obtained for the red brick may be regarded to fall within the normal range, the figure for the yellow brick exceeded the upper limit.

The use of the consolidant reduced porosity by $4 \%$ in both types of specimens; this effect was due to the precipitation of the silica gel in the pore system of the brick as a result of hydrolysis and polymerization of ethyl silicate.

Porosity also declined (by 2-3\%) in the combined consolidant-water repellent treatment as a result of the presence of the water repellent in the pore walls. The smaller decline can be attributed to reduced product deposition, because lower quantities of the active compound were present.

Pore size distribution varied considerably in the two brick types (Figures $6 \mathrm{a}$ and $7 \mathrm{a}$ ). All the pores in the red brick had a radius of under $1 \mu \mathrm{m}$, with a sizeable fraction smaller than $0.1 \mu \mathrm{m}$. By contrast, the yellow brick had a large volume of pores ranging in size from 0.1 to $1 \mu \mathrm{m}$, very few pores under $0.1 \mu \mathrm{m}$, and a substantial fraction with a radius of $4 \mu \mathrm{m}$.

In calcareous bricks fired at temperatures of under $1,100{ }^{\circ} \mathrm{C}$, most of the pore volume is ordinarily accounted for by pores with radii of from 0.01 to $1 \mu \mathrm{m}$ (19). Mercury intrusion porosimetry and digital imaging analysis (19) have shown that in calcareous brick fired at $800{ }^{\circ} \mathrm{C}$ and (especially) at $900^{\circ} \mathrm{C}$ pore radius tends to be over $>1 \mu \mathrm{m}$.

Pore size distribution was observed to vary slightly after the treatments were applied. The treated red 
b y c) debido a la heterogeneidad del material y al pequeño tamaño de las muestras que se utilizan en esta técnica, ha resultado que las muestras tratadas tienen una mayor porosidad que las sin tratar; ya se ha visto en la medida de la porosidad al agua (donde se utilizan muestras mayores $\mathrm{y}$, por tanto, más representativas) que el efecto es de disminución de porosidad, por lo que este hecho se podría justificar bien por una diferencia intrínseca entre las muestras previa a la aplicación de los tratamientos, bien a que los poros muy grandes, que no detecta el porosímetro, se han llenado parcialmente y pasan a ser medidos. A pesar de esta diferencia, las distribuciones de tamaños de poros para las tres muestras son muy semejantes, por lo que podría concluirse que el efecto de los tratamientos es muy ligero. Puede observarse que los dos tratamientos hacen disminuir ligeramente el volumen de poros entre 0,1 y $0,01 \mu \mathrm{m}$, aunque todavía existe un gran volumen de poros de tamaño inferior a $1 \mu \mathrm{m}$. Este efecto sería beneficioso de cara a su respuesta frente a la alteración.

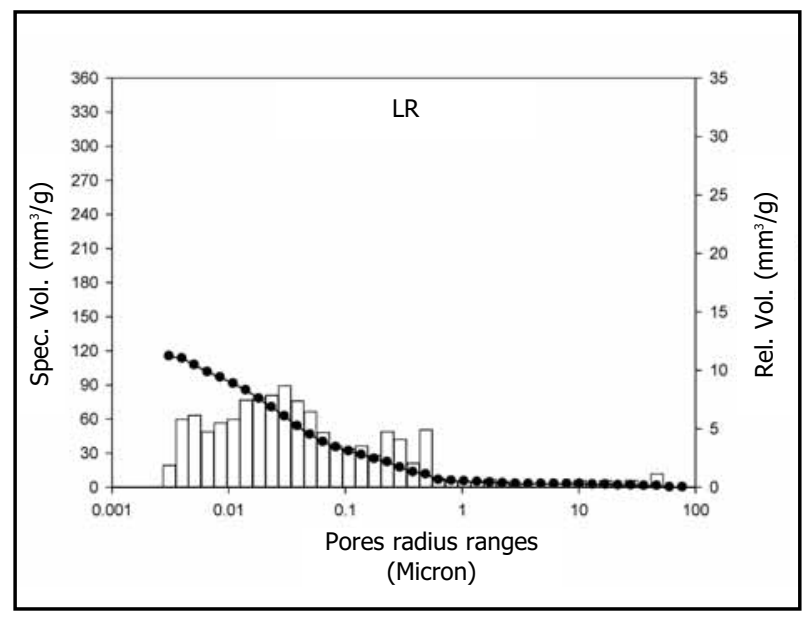

brick samples (Figures 6a, b, c) had higher porosity than the untreated specimens. This apparent anomaly may have been due to material heterogeneity and the small sample size. The water porosity test, in which larger (and therefore more representative) samples were used, showed lower porosity. This result may denote an intrinsic difference in the untreated samples or the presence of larger pores initially undetected by the porosimeter that, once filled with product, would have become measurable. Despite this difference, the pore size distributions in the three samples were fairly similar, indicating that the effect of the treatments was very slight. Note the slight decline in the volume of the 0.1-0.01- $\mu \mathrm{m}$ pore size with both treatments, despite the large volume of $<1-\mu m$ pores. This effect enhanced their resistance to decay.
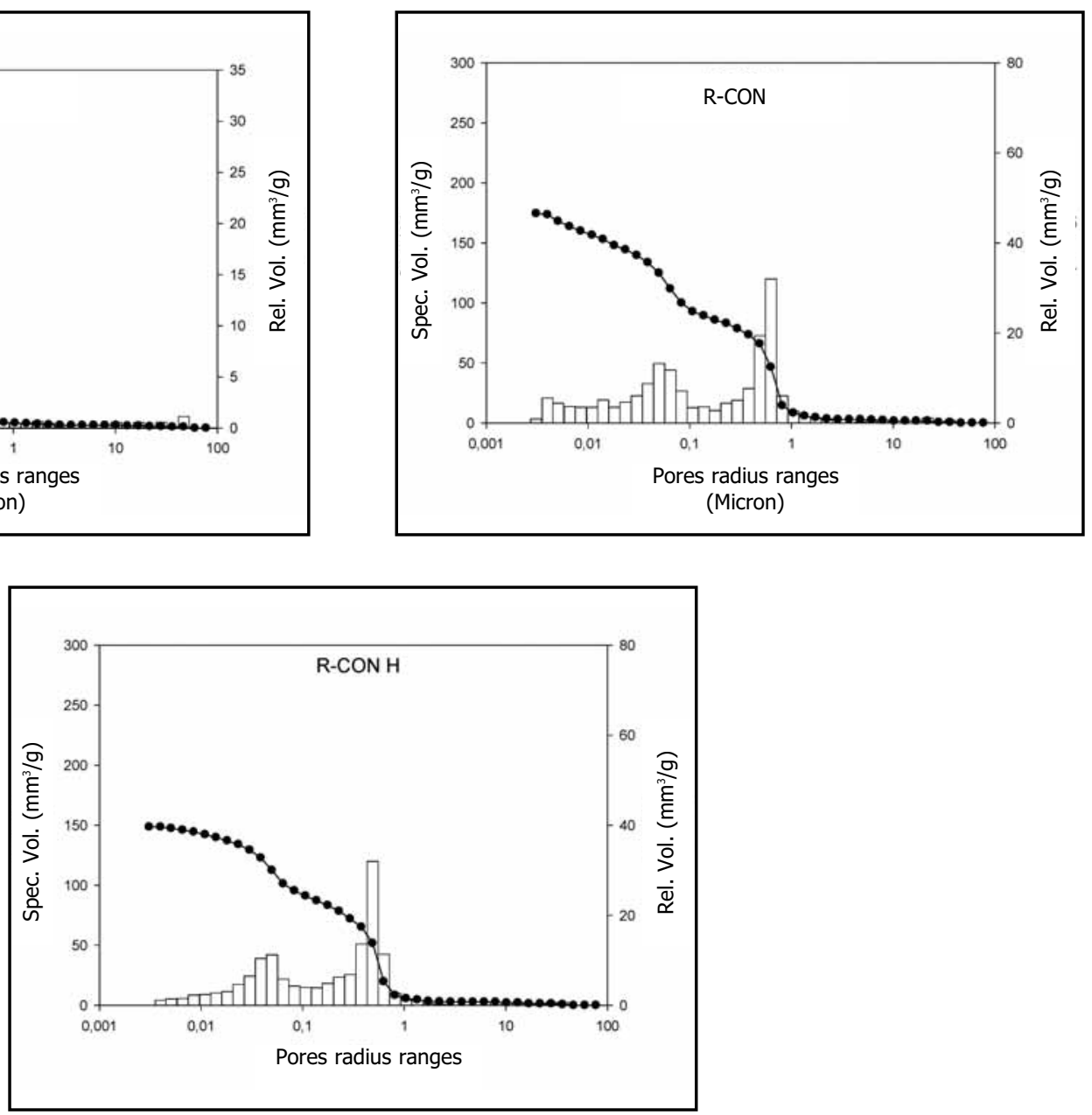

Figura 6. Distribución de tamaño de poros del ladrillo rojo. a) sin tratar; b) tratado con el consolidante; c) tratado con consolidante e hidrófugo.

Figure 6. Red brick pore-size distribution: a) untreated; b) treated with consolidant; c) treated with consolidant plus water repellent. 

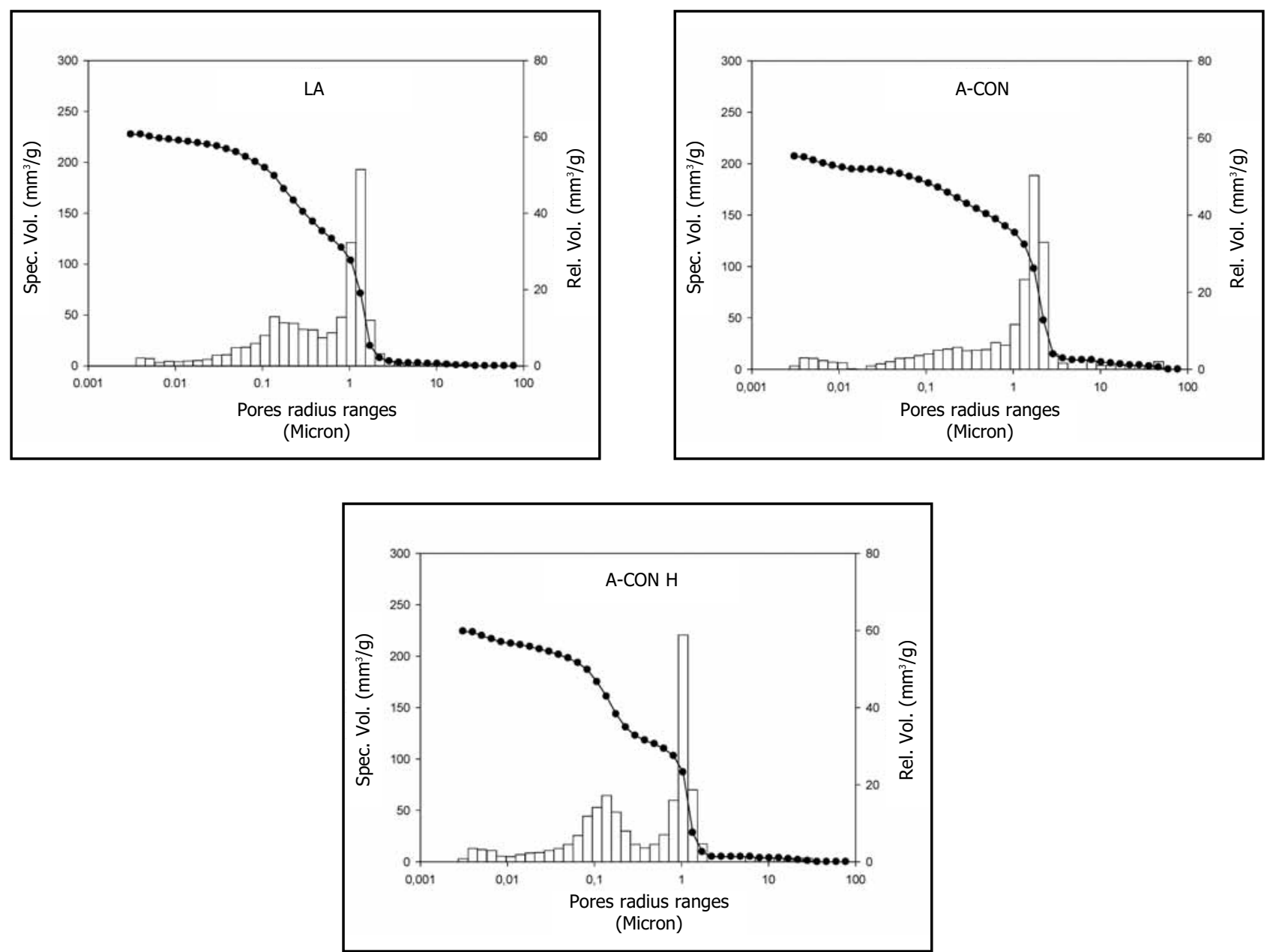

Figura 7. Distribución de tamaño de poros del ladrillo amarillo. a) sin tratar; b) tratado con el consolidante; c) tratado con consolidante e hidrófugo.

Figure 7. Yellow brick pore-size distribution: a) untreated; b) treated with consolidant; c) treated with consolidant plus water repellent.

En el ladrillo amarillo se observa el efecto contrario (Figuras $7 a, b$ y c), se desplaza el intervalo de mayor volumen de poros hacia menores radios. Este cambio es muy pequeño y no llega a afectar significativamente a la distribución porosimétrica y, por tanto, a su comportamiento frente a la cristalización de sales. Ahora sí se aprecia una menor porosidad total en las muestras tratadas.

\subsubsection{Eficacia del tratamiento}

En la Figura 8 se representa la absorción de agua por capilaridad (incremento de peso relativo al peso seco) frente a la raíz cuadrada del tiempo ( $\left.\mathrm{s}^{1 / 2}\right)$.

Se puede observar que los dos tratamientos producen una disminución importante en la absorción de agua. Tanto en las muestras de ladrillo rojo como el amarillo, el producto consolidante ha producido una reducción considerable en la absorción de agua (especialmente en este
The opposite trend was observed in the yellow brick samples, with pore volumes shifting towards smaller radii (Figure $7 a, b, c)$. This change was too slight, however, to significantly affect pore size distribution or, therefore, the response to salt crystallization. Total porosity declined in treated as compared to untreated yellow-brick samples.

\subsubsection{Treatment effectiveness}

Capillary water uptake (weight gain relative to dry weight) is plotted against the square root of time $\left(s^{1 / 2}\right)$ in Figure 8.

Note that water absorption declined significantly with both treatments. The consolidant generated the steepest drop in both the red and yellow bricks, but particularly in the latter. This may have been the outcome of the minor water repellence afforded 


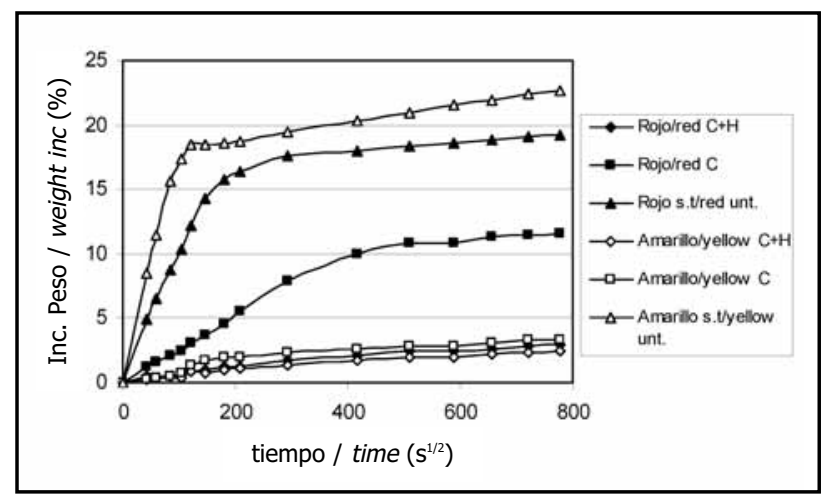

Figura 8. Absorción capilar de las probetas.

Figure 8. Capillary water absorption of samples.

último), pudiendo deberse este hecho al ligero efecto hidrófugo que pueda tener el tratamiento (por restos de grupos orgánicos sin polimerizar, fundamentalmente).

El tratamiento consolidante + hidrofugante ha originado una nueva reducción de la absorción de agua por capilaridad en la muestra correspondiente al ladrillo rojo, pero en cambio no ha tenido efecto el tratamiento adicional del hidrofugante sobre la capilaridad del ladrillo amarillo con consolidante.

Los datos obtenidos con respecto a la dureza superficial corresponden a la media de 36 valores y se recogen en la Tabla 5. primarily by the remains of non-polymerized organic groups.

The consolidant+water repellent treatment further decreased capillary water uptake in the red brick sample, but had no additional effect on capillarity in the yellow brick.

The surface hardness findings, the mean of 36 measurements, are given in Table 5.

Tabla 5 / Table 5

Dureza superficial Brinell. Brinell surface hardness.

\begin{tabular}{|c|c|c|c|}
\hline Ladrillo / Brick & Sin Tratamiento / Untreated & Estel 1000 & Estel 1000 + FTB Hydro es \\
\hline Rojo / Red & 94.31 & 94.06 & 95.33 \\
\hline Amarillo / Yellow & 85.86 & 84.5 & 84.3 \\
\hline
\end{tabular}

Al igual que la resistencia a compresión, se observa cómo la dureza superficial del ladrillo rojo es superior a la del amarillo. El origen de esta diferencia se encuentra muy probablemente en la mayor compacidad que tienen los ladrillos rojos, ya que mientras más poroso es un material menor es su dureza superficial.

Respecto a la influencia que han tenido los tratamientos del consolidante o del consolidante + hidrofugante sobre la dureza superficial de las muestras se puede apreciar que no se han producido cambios significativos.

\subsubsection{Resistencia a la alteración}

En la Figura 9 se representa la evolución de pesos medios para cada tipo de ladrillo a lo largo del ensayo de cristalización de sales, expresada como incremento respecto al peso original.
As in the case of compressive strength, the red brick had a clearly harder surface than the yellow brick. The difference was probably due to its greater compactness, for higher porosity leads to lower surface hardness.

No significant changes were observed in sample surface hardness after treatment with the consolidant or the consolidant+water repellent.

\subsubsection{Durability}

Figure 9 gives the mean weights of each brick type throughout the salt crystallisation test, expressed as an increase relative to the original weight. 


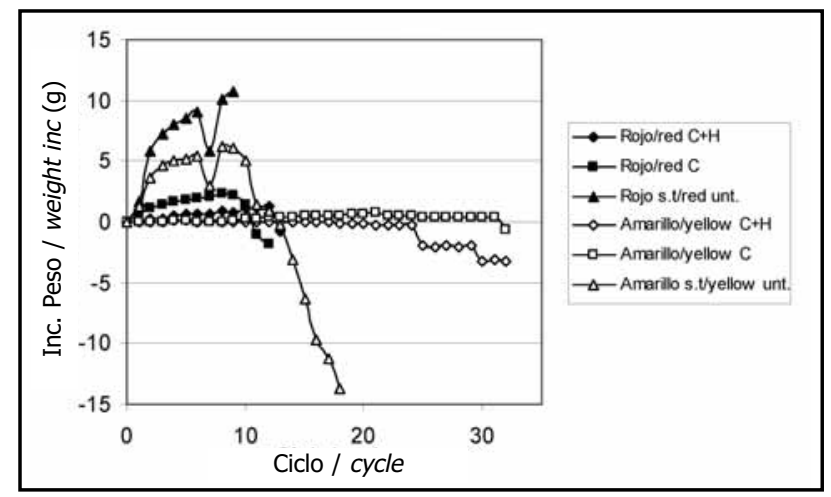

Figura 9. Evolución de pesos en el ensayo de cristalización de sales.

Figure 9. Weight versus time during salt crystallization test.

\section{Ladrillo rojo}

Las primeras alteraciones importantes han aparecido a los diez ciclos de cristalización, observándose la fracturación de las probetas sin tratamiento al igual que las tratadas sólo con el consolidante. Este hecho indica que el tratamiento sólo con consolidante no mejora su resistencia a la cristalización de sales. A partir de los trece ciclos de cristalización las probetas con tratamiento consolidante más hidrofugante se han fracturado mostrando la misma morfología de alteración, por lo que se puede concluir que la combinación de ambos tratamientos mejora ligeramente la durabilidad de los ladrillos rojos frente a este tipo de mecanismo de deterioro, pero no cambia la morfología de la alteración.

\section{Ladrillo amarillo}

Las probetas de ladrillo amarillo han tenido mucho mejor comportamiento frente al ensayo de cristalización de sales; así, a los diez ciclos sólo las probetas sin tratar comienzan a alterarse, apreciándose el desprendimiento

\section{Red brick}

The first visible changes appeared after 10 crystallisation cycles, when both the untreated samples and the samples treated with the consolidant only began to break. The consolidant alone obviously failed to improve resistance to salt crystallisation. After 13 cycles, the consolidant+water repellent-treated samples broke in the same way, indicating that the combination of the two products improved red brick resistance to this type of weathering slightly, but did not alter the weathering pattern.

\section{Yellow brick}

The yellow brick samples performed much better in the salt crystallization test. After ten cycles, weathering was observed in the untreated samples only, which exhibited even crumbling across the entire surface, with rounding

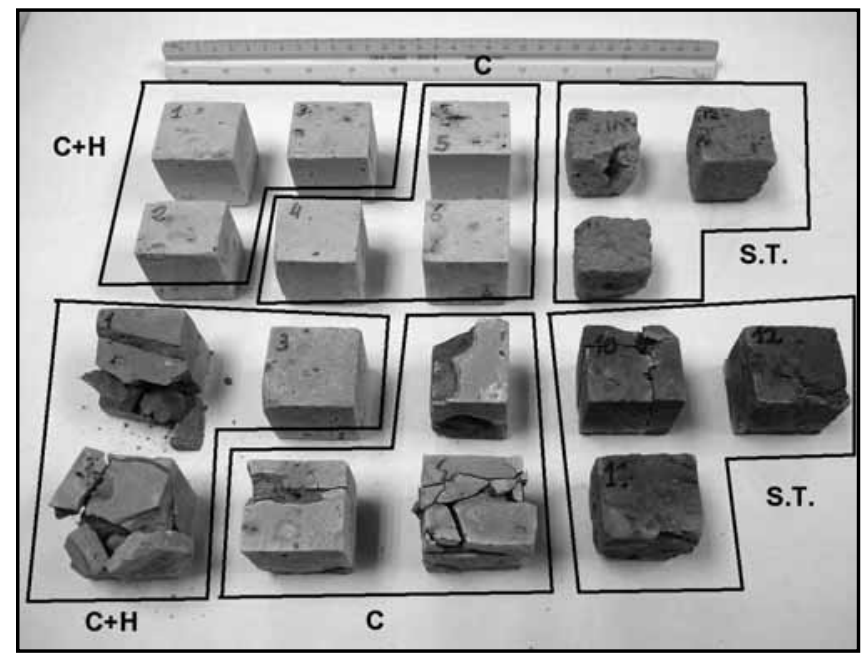

Figura 10. Probetas tras 15 ciclos de cristalización de sales. Figure 10. Samples after 15 salt crystallization cycles. 
de partículas uniformemente en toda la superficie, de forma que las aristas y los vértices se van redondeando. Esta alteración se ha visto incrementada a los 15 ciclos de cristalización, pero no ha habido rotura de fragmentos grandes sino disgregación progresiva. Las probetas tratadas no han experimentado ningún tipo de alteración después de 32 ciclos (al finalizar el ensayo), por lo que se puede concluir que ambos tratamientos mejoran la durabilidad de este material frente a la cristalización de sales.

\section{Comparativa}

La diferente morfología de alteración que han tenido los ladrillos rojos, que se fracturan en varios trozos de gran tamaño, frente a los ladrillos amarillos, en los que se desprenden partículas uniformemente en toda la superficie, de forma que las aristas y los vértices se van redondeando, se puede explicar por la diferencia en el tamaño de poros. De esta manera, al ser más pequeños en el ladrillo rojo, las presiones de cristalización son más elevadas y, a pesar de la mayor resistencia a compresión de éste, provocan la rotura del material en fragmentos. En el ladrillo amarillo los poros son de mayor diámetro, por lo que se generan unas tensiones de cristalización inferiores que desencadenan la disgregación más lenta del material.

Esta morfología de deterioro se ha observado también en materiales pétreos con un volumen elevado de microporos, como es el caso de la piedra de Espera, empleada en la Catedral de Sevilla (22), la de Almería, en la Catedral de dicha ciudad (22), o la de Bácor, usada en la Catedral de Guadix (8). En ellas se aprecia igualmente que los tratamientos ejercen menor efecto, en algunos casos casi inapreciable, en la resistencia a la alteración y en la morfología de deterioro en las probetas sometidas al ensayo de cristalización de sales.

\section{CONCLUSIONES}

A partir de los resultados obtenidos con los diferentes estudios y ensayos se pueden extraer las siguientes conclusiones.

El ladrillo rojo se caracteriza por una porosidad elevada con tamaños de poros mayoritariamente por debajo de $1 \mu \mathrm{m}$. Por ello, la absorción total de agua es alta pero se realiza con una velocidad inicial media. Sus propiedades mecánicas están en relación a su compacidad, tanto la resistencia a compresión como la dureza superficial son altas.

El ladrillo amarillo presenta una porosidad total algo mayor, pero la distribución de tamaños de poros es muy diferente, estando en su mayor parte por encima de $1 \mu \mathrm{m}$. of corners and edges. While decay was more intense after 15 cycles, it continued to consist in gradual crumbling, with no detachment of large fragments. The absence of any decay whatsoever in the treated samples after the full 32 test cycles provided conclusive proof that both treatments effectively enhanced material resistance to salt crystallization.

\section{Comparison}

Differences in pore size may explain the contrast in the effects of weathering in these two types of brick. With smaller pores, the red brick samples were subjected to higher crystallization pressure. Consequently, despite the higher compressive strength of this material, it broke into fragments under accelerated crystallization ageing. The larger pores in the yellow brick led to lower crystallisation pressures, and concomitantly slower crumbling.

This type of decay has also been observed in stones with high micropore volumes, such as the Espera stone (province of Seville) used in Seville Cathedral (22), the stone from Almería used in the eponymous cathedral (22), and the stone from Bácor (province of Granada) used in Guadix Cathedral (8). When subjected to salt crystallization trials, samples of these stones also proved to be essentially impervious to treatment (whose effects were nearly negligible in some cases) with respect to ageing and the pattern of decay.

\section{CONCLUSIONS}

A number of relevant conclusions can be drawn from the above findings.

With high porosity and pore sizes mostly under $1 \mu \mathrm{m}$, the red brick exhibited high total water absorption, although the initial uptake was moderate. A very compact material, this brick exhibited good mechanical properties, including high compressive strength and surface hardness.

The total porosity found for the yellow brick was higher and the pore size distribution was quite different, with most pores larger than $1 \mu \mathrm{m}$. Total absorption was 
La cantidad de agua que absorbe es mayor que el anterior y también lo hace a mayor velocidad inicialmente. Sus propiedades mecánicas son ligeramente inferiores, como consecuencia de su menor compacidad.

Su respuesta frente a la cristalización de sales es muy diferente. El ladrillo rojo se altera en un plazo más corto, fracturándose la probeta en fragmentos grandes, como consecuencia de la presión que ejercen los cristales de la sal dentro de los pequeños poros que presenta el material. El amarillo se altera bastante más despacio (comienza el deterioro en el ciclo décimo) y por disgregación superficial de la probeta, ya que al tener poros de mayor tamaño la presión debida a la cristalización es menor.

Este resultado corrobora el hecho observado en la fachada de la Capilla, los ladrillos rojos tienen menor durabilidad frente a la cristalización de sales que los amarillos y se ha apreciado la misma morfología macroscópica de alteración que aparece en la fachada, la ruptura de grandes fragmentos en el ladrillo rojo y la arenización superficial del amarillo.

En ambos casos los tratamientos hacen disminuir la porosidad total sin afectar de manera significativa a la distribución de tamaños de poros. Sin embargo, la dureza superficial no experimenta ningún cambio. La absorción de agua sí se ve modificada, de manera que tanto la velocidad de absorción como la cantidad total absorbida disminuyen, en mayor medida, con el hidrófugo pero también de manera apreciable con el consolidante.

El efecto sobre la alterabilidad es diferente según el tipo de ladrillo. En el ladrillo rojo ninguno de los dos tratamientos produce una mejora sustancial en la resistencia a la alteración. Las probetas tratadas sólo con el consolidante experimentan la misma morfología de deterioro que las sin tratar casi en el mismo punto del ensayo. Las probetas tratadas también con el hidrófugo resisten un número de ciclos algo mayor, pero sin que la variación pueda considerarse un resultado claramente positivo. En el ladrillo amarillo sí que se observa un comportamiento mucho mejor en las probetas tratadas. Hasta que se ha dado por finalizado el ensayo a los 32 ciclos, prácticamente no habían aparecido alteraciones en dichas probetas, mientras que las probetas sin tratar comienzan a alterarse a partir del décimo ciclo.

Es importante destacar el papel decisivo que tiene la distribución del tamaño de poros en la resistencia a la alteración por cristalización de sales, así como en la morfología de deterioro, que se repite tanto en el monumento como en el ensayo de laboratorio, al igual que en materiales pétreos. Este parámetro condiciona el efecto de los tratamientos, hasta el punto de hacerlos poco útiles. greater and initial uptake was faster. As a result, the yellow brick was less compact and its mechanical performance was slightly poorer.

The two types of specimens also behaved differently in the salt crystallization tests. The red brick decayed after a short number of cycles, with large fragments detaching under the pressure of salt crystals inside its small pores. By contrast, the onset of deterioration came later in the yellow brick (after the 10 th cycle) and adopted the form of surface crumbling, the outcome of the lower crystallization pressure in its larger pores.

These results are consistent with the actual condition of the chapel facade, whose red brick is visibly more deteriorated than the yellow variety. Moreover, the macroscopic pattern of decay was the same as in the test, with large fragments missing from the red brick and surface crumbling observed on the yellow.

In both cases, the treatments reduced total porosity without significantly affecting pore size distribution. While this had no effect on surface hardness in either type of brick, water absorption was altered, with declines in both the uptake rate and total absorption. The changes were greatest in the samples treated with the water repellent, but appreciable differences were also observed in the specimens impregnated with consolidant only.

Treatment affected the two types of brick differently. In the red material, resistance was not substantially enhanced by either treatment, with the samples treated with the consolidant only exhibiting the same pattern of decay as the untreated specimens after nearly the same number of cycles. Samples treated with both products were slightly more resistant, but the difference was not large enough to be conclusive. The treated yellow brick specimens were much more decayresistant than the untreated samples: the former remained nearly intact after the full 32 cycles, whereas the untreated samples began to weather after the $10^{\text {th }}$ cycle.

Pore size distribution clearly plays a decisive role in salt crystallization-induced ageing and the type of decay generated. This was borne out by in situ observations on the chapel as well as laboratory findings and the literature on stone. Depending on this parameter, treatment may be effective or nearly useless. 
En resumen, en el ladrillo rojo la aplicación de tratamientos no mejora su respuesta frente a los agentes de deterioro, si bien tampoco la empeora, mientras que en el amarillo sí se obtiene un comportamiento mucho mejor. Dado que en la intervención en el edificio no es posible realizar el tratamiento de forma selectiva, la decisión fue aplicar el mismo tratamiento para los dos.

\section{AGRADECIMIENTOS}

Nuestro agradecimiento a D. Carlos Núñez Guerrero, restaurador responsable de la intervención en la capilla de Santa María de Jesús. Gracias también a doña Cristina Laurin por la versión inglesa del texto.
By way of summary, while the red brick performed neither better nor worse when treated, weather resistance improved substantially in treated yellow brick. Inasmuch as selective application of the treatments would have been impractical, the decision adopted was to treat both types of brick with the same product.

\section{ACKNOWLEDGEMENTS}

The authors wish to thank Carlos Núñez Guerrero, head restorer of the Santa María de Jesús Chapel rehabilitation works, for his cooperation. Thanks also go to Christine Laurin for the English version of the text.

\section{BIBLIOGRAFÍA / BIBLIOGRAPHY}

(1) http://www.us.es/informacion/Historia

(2) http://www.personal.us.es/alporu/historia/index.htm

(3) UNE-EN 772-1: "Métodos de ensayo de piezas para fábrica de albañilería. Parte 1: Determinación de la resistencia a compresión" (2002).

(4) Villegas, R.: "Metodología para la evaluación y estudio previo de tratamientos". Metodología de diagnóstico y evaluación de tratamientos para la conservación de los Edificios Históricos. Consejería de Cultura. Instituto Andaluz del Patrimonio Histórico (2003), pp. 194-207.

(5) Villegas, R.; Espinosa, J.: "Evaluación de productos de tratamiento para la portada de la iglesia de Santiago de Guadix". Mater. Construcc., vol. 51, no 261 (2001), pp. 21-32.

(6) Alejandre, F. J.; Villegas, R.; Jurado, M.: "Evaluación del comportamiento de materiales empleados en la reintegración de materiales cerámicos de la Plaza de España (Sevilla)". Mater. Construcc., vol. 55, no 278 (2005), pp. 69-76.

(7) EN-1936: "Determination of a real density and apparent density, and of total and open porosity" (1999).

(8) RILEM COMMISSION 25-PEM: "Protection et érosion des monuments. Essais recommandés pour mesurer l'altération des pierres et évaluer l'efficacité des méthodes de traitement". Commission 25-PEM, Protection et Érosion des Monuments. Doc. PEM 73/10 (1980).

(9) Alcalde, M.; Bello, M. A.; Espinosa, J.; Martín, A.; Ontiveros, E.; Rodríguez, C.; Sameño, M.; Sebastián, E.; Villegas, R.: "Piedra Natural". Programa de Normalización de Estudios Previos aplicado a Bienes Inmuebles. Consejería de Cultura. Instituto Andaluz del Patrimonio Histórico (2006), pp. 20-91.

(10) Van Hees, R. P. J.; Brocken, H. J. P.: "Damage development to treated brick masonry in a long term salt crystallisation test. Construction and building materials", n० 18 (2004), pp. 331-338. doi:10.1016/j.conbuildmat.2004.02.006

(11) Steiger, M.: "Crystal Growth in Porous Materials-I: The Crystallization Pressure of Large Crystals". Journal of Crystal Growth, 282 (2005), pp. 455-469. doi:10.1016/j.jcrysgro.2005.05.007

(12) Flatt, R. J.: "Salt Damage in Porous Materials: How High Supersaturation are Generated". Journal of Crystal Growth, 242 (2002), pp. 435-454. doi:10.1016/S0022-0248(02)01429-X

(13) Rodríguez-Navarro, C.; Doehne, E.; Sebastián, E.: "How does Sodium Sulfate Crystallize? Implications for the Decay and Testing of Building Materials". Cem. Concr. Res., 30 (2000), pp. 1527-1534. doi:10.1016/S0008-8846(00)00381-1

(14) Steiger, M.: "Crystal Growth in Porous Materials-II: Influence of Crystal Size on the Crystallization Pressure". Journal of Crystal Growth, 282 (2005), pp. 470-481. doi:10.1016/j.jcrysgro.2005.05.008

(15) Steiger, M.: "Crystal Growth in Porous Materials: Influence of Supersaturation and Crystal Size". Álvarez de Buergo; GómezHeras; Vázquez-Calvo (eds.): Heritage, Weathering and Conservation, Taylor and Francis Group, London (2006), pp. $245-251$.

(16) Peters, T.; Iberg, R.: "Mineralogical changes during firing of calcium-rich brick clays". Ceram. Bull., 57 (1978), pp. 503-509.

(17) Alcalde, M.; Villegas, R.; Vale, J.; Martín, A.: "Diagnosis y Tratamiento de la Piedra I. La alteración de la piedra en los monumentos. II. Consolidantes e hidrófugos. Productos para el tratamiento de materiales pétreos". Monog. no 400, ICCE. Torroja (CSIC), Madrid (1990).

(18) Lazzarini, L.; Laurenzi-Tabasso, M.: "Il Restauro della pietra". Ed. CEDAM, Padova (1986). 
(19) Cultrone, G.; Sebastián, E.; Elerta, K.; Torre, M. J. de la; Cazalla, O.; Rodríguez Navarro, C.: "Influence of Mineralogy and Firing Temperature on the Porosity of Bricks". Journal of the European Ceramic Society, 24 (2004), pp. 547-564. doi:10.1016/S0955-2219(03)00249-8

(20) González I., Palán, E., Miras, A., Aparicio, P.: "New Uses for Brick-making Clay Materials from the Bailen Area (Southern Spain)". Clay Minerals, 33 (1998), pp. 453-465. doi:10.1180/000985598545750

(21) Cultrone, G.: "Estudio mineralógico-petrográfico y físico-mecánico de ladrillos macizos para su aplicación en intervenciones del Patrimonio Histórico". Tesis Doctoral. Departamento de Mineralogía y Petrología, Universidad de Granada (2001).

(22) Villegas, R.: "Estudio de la alterabilidad y respuesta a tratamientos de conservación de los principales tipos de piedra utilizados en catedrales andaluzas". Tesis Doctoral. Departamento de Ingeniería Química y Ambiental, Universidad de Sevilla (1989). 